\title{
The Influence of the Non-Financial Features on the Earnings Management Process: The Case of the BSE Listed Companies
}

\author{
Mihai Carp and Iuliana Eugenia Georgescu
}

\author{
Alexandru Ioan Cuza University of Iaşi, Romania \\ Correspondence should be addressed to: Mihai Carp and Iuliana, mihai.carp@feaa.uaic.ro;
}

Received date: 1 April 2015; Accepted date: 26 June 2015; Published date: 12 May 2016

Copyright (C) 2016. Mihai Carp and Iuliana Eugenia Georgescu. Distributed under Creative Commons CC-BY 4.0

\begin{abstract}
The estimation of the earnings management facilitates the evaluation from the quantitative perspective of the quality of the accounting basic product, the financial information. By being the expression of the extent to which a faithful representation of the economic reality is made, the earnings management especially calls for the neutrality of the approaches that are associated to the elaboration of the financial statements. The diversity of the features that individualize the reporting entities represents a series of limits when making a unitary appreciation of the qualitative level of the transmitted information. The paper aims at realizing an exploratory study on the influences of a series of non-financial features (activity field, reputation of the auditing company, the expressed opinion, the structure of the shareholders, the type of the applied control, the nationality of the capital) of the companies listed on the regulated section of the BSE, on the intensity of the reported financial earnings management. Data extracted from the financial statements issued by the 62 companies in the study, for the last 4 financial exercises (2010-2013), have supported the making of 248 observations on the features that are associated to the analysis of the earnings management process.
\end{abstract}

Keywords: earnings management, quality of the financial information, discretionary accruals, regression analysis

\section{Introduction}

The accounting result, as an expression of the performance of an entity, is of special importance for the users of the information in the financial statements, since it is an indicator of the extent to which that specific entity was involved in value-adding activities.

The performance of an entity is seen differently according to the divergent

Cite this Article as: Mihai Carp and Iuliana Eugenia Georgescu (2016)," The Influence of the Non-Financial Features on the Earnings Management Process: The Case of the BSE Listed Companies ", Journal of Eastern Europe Research in Business and Economics, Vol. 2016 (2016), Article ID 386814, DOI: 10.5171/2016.386814 
interests of the various user groups. Besides the classical meanings, the performance of an entity may be evaluated according to its ability to create value, and the variances of the results according to the market values change the economic performance of the company. Under these circumstances, the new measure of performance risks to reflect the modifications of the environment and of the financial markets rather than those that can be explained by the entity's activity (Berheci, 2010).

According to McKee (2005), the theoretical value of the shares of an entity is practically the present value of its future results. Lev (1989) established that there is a directly proportional connection between a company's results and its value. Francis et al. (2003) concluded that the result can be associated with the share price rather than with the cash flow, the sales flow, or other financial data. In the opinion of Ronnen and Yaari (2008), shareholders use the results' information both in order to evaluate the performance of the managers as administrators of the entity's wealth and in order to anticipate future cash flows and to evaluate risks.

Considering the importance of the result information for the users, it is obvious that a correct evaluation of the performance of an entity depends on the quality of the accounting information in general and on the quality of the result in particular.

\section{Ways of Altering the Neutrality of the Financial Information on Performance}

One of the current topics concerning the conceptualisation of the aspects related to the quality of information on an entity's results is earnings management (EM). There are several definitions of this concept. Thus, in Schipper's (1989) opinion, it is a voluntary intervention in the process of external financial reporting, with the purpose of obtaining certain benefits. According to Healy and Wahlen (1999), "earnings management occurs when the managers intervene in financial reporting and in structuring the transactions, aiming to modify them either in order to mislead the other users with regards to the economic performance of the company, or to influence the contractual relationships that depend on the reported accounting data". A more conservative definition belongs to McKee (2005), who states that earnings management consists in making reasonable and legal managerial decisions with the purpose of reporting stable and predictable financial results. He stresses the fact that earnings management should not be mistaken for other activities that do not reflect the economic reality, in which case we can speak about fraud.

An analysis of the definitions given to earnings management, according to the perspective - which may be conservatory, moderate, aggressive, or even fraudulent allowed Ronnen and Yaari (2008) to classify it as: white, grey, and black. While "white" earnings management (also called beneficial earnings management) aims at improving the transparency of financial reporting, "black" management involves fake declarations, a reduced transparency, or even fraud. "Grey" earnings management is based on selecting accounting models either to the purpose of maximizing the managers' wealth or to the benefit of the entity. Therefore, earnings management may be beneficial in the sense that it illustrates the value of the entity on the long term, but it is harmful when it hides the real value of the entity on the long or on the short term and, finally, it can be neutral when it stresses the real performance of the entity on the short term.

Earnings management is possible due to the synchronization differences which can appear between the accrual accounting and the cash accounting. Parfet (2000) makes the difference between the "bad" and the "good" earnings management. The bad one consists of the intervention in order to hide the real performance by creating artificial entries or by overpassing the estimations over a reasonable level when preparing the 
financial statements. The good earnings management implies the managers' decision making which is to lead to stable financial performances, in the context of markets' competition and evolution, by efficiently using the resources and through a fast reaction against unpredicted situations. The same author concludes that earnings management is not a bad thing, but a reflection of the expectancies from the inside and the outside of the entities of all the stakeholders on the capital market.

Omar et al. (2014), Abernathy et al. (2014) identify three main forms of EM: accruals earnings management - AEM; real earnings management - REM; classification shiftingCS.

From McVay's (2006) opinion, through CS, managers reclassify the structures in the financial statements, in order to reach result indicators which are to correspond to the analysts' previsions. This strategy leads, according to Haw et al. (2011), to a weakening of the financial information credibility, by misleading investors, and also influencing the share price, respectively the stability of the financial markets.

Real earnings management is one method through which the reported results are modified, to a certain extent, and which consists of changing the moment in which the structure of some operational, investment or financing transactions is modified or when they are recognized (Zang, 2012). To this regard, Ge and Kim (2014) claim that, in order to reach certain levels of the financial results, managers interfere in the normal activity of transactions through actions that can be grouped in three categories: sales management (providing commercial discounts for short periods of time, in order to increase the sales; relaxing conditions regarding the commercial credit sales), overproduction (in order to reduce the production cost), and reduction of the discretionary expenses (especially the research-development expenses).
By displaying the differentiation elements between the principles of the accruals accounting and the ones of the cash accounting, accruals represent the most frequently managed structures. The main way of managing the earnings is the accruals earnings management, as, from Tsipouridou and Spathis's opinion (2012), these are elements that do not imply the discount (that do not modify the cash-flows). Shareholders prefer investing in entities which report consistent growths and not in the ones that change their results or which are uncertain. Due to this fact, managers are influenced to use accruals accounting techniques in order to timely manage the result. These techniques can aim, from case to case: provisions for risks and expenses, adjustments for assets' depreciation, amortizations, etc (Ranking, 2012).

Of the frequently met complementary earnings management techniques, we remind: the smoothing of earnings and the recognition of loses which is known as the "big bath" technique.

From Copeland's (1968) opinion, the earnings smoothing annually moderates the fluctuations of incomes by transferring the profits of the top years to the less successful periods. In practice, a series of accrual accounting techniques are used, such as: the recognition in advance of the sales income, the variation of the risks and expenses provisions, the late recognition of the assets' depreciation. The Big Bath technique is used, according to Omar et al. (2014), when companies register loses form restructuring operations, by selling some operational or subsidiary units, and when they decide to completely recognize it in a specific period.

\section{Factors that Influence the Process of Earnings Management}

The manifestation of the earnings management process has represented a highly debated subject, its quantification being made according to a wide variety of factors, which influence the activity of 
companies, and especially according to the ones that can significantly influence the operations that allow the modification of the financial information quality. Amongst the most frequently used disjunctive factors that determine the level of earnings management, we enumerate: the specific of the legal regulation (of the accounting standards), the legal system (based on rule codes or customary systems), the features of the financial systems (market oriented; bankbased), investors' protection, the companies' features (size, governance, activity field), the certification process of the financial statements (auditors' reputation, the type of expressed opinion) etc. All these factors of the analysis carried on the identified phenomenon aim at emphasizing the situations that ease the presence of earnings management, implicitly proposing limitation measures of its effects.

Lee and Chen (2011) analyse the connection between a company's value and the compensations offered to its managers. The authors notice an increase in the intensity of this link corresponding to an enhancement of the material benefits obtained by its management, justifying this evolution by the significant motivational impact of the correlation of the managers' retribution with the growth of the company's value.

This deterministic relationship creates, nevertheless, possible difficulties in preserving the unaltered quality of the reported information, since managers are tempted to manipulate the obtained earnings, with the purpose of increasing their contractual compensations. For this reason, Sun et al. (2014) consider that, in order to limit the earnings management process, it is necessary for the financial statements to be certified by an independent audit committee, even with an enhanced risk for it not to be detected, generated by the specialisation of the activity of the economic entities.

In this respect, authors such as Rusmin (2010), Iatridis (2011) stress the disjunctive role of the reputation of audit companies on the intensity of the earnings management process, signalling a reduction of management practices in the case of entities whose financial statements were audited by companies members of the Big4.

On the same line of the influence of the companies' characteristics on the quality of financial information, El Mehdi and Seboui (2011), Datta et al. (2013) mention the activity field as a factor that contributes to dimensioning the analysed phenomenon. Iqbal and Strong (2010) identify the link between the application of the principles of corporate governance, respectively the structure of the management bodies and the quality level of the published financial information. Focusing on the Greek economic context, Tsipouridou and Spathis (2012) study the extent of earnings management in correlation with a series of factors such as: the company size, the expressed audit opinion, or the specificity of the accounting norms (national or international). The shareholders' structure is taken into consideration by Ghosh (2010) as a determinant in the causal relation between earnings management and the nationality of the audit company, revealing at the same time the significant impact on the EM of the activity field, the audit opinion, the audit fees, and the companies' performance.

\section{Objective of the Study}

Starting from the theoretical aspects of earnings management identified in specialised literature, we aim to perform an exploratory study on the influences exerted by a series of non-financial features of the companies quoted on the regulated section of the BSE on the intensity of the management process of the reported earnings. Estimating the extent of earnings management facilitates the appreciation in a quantitative dimension of the quality of the basic product of accounting. Being the expression of the extent to which a faithful representation of the economic reality is achieved, EM resorts especially to the neutrality of the approaches 
associated with drawing the financial statements.

\section{Work Hypotheses}

In order to meet the research objectives, we suggest testing the following work hypotheses:

H1: A series of non-financial factors (the activity field, the reputation of the audit company, the expressed opinion, the shareholders' structure, the type of control exerted, the nationality of the capital) determine the degree of earnings management in the case of the BSE-quoted companies.

H2: It is possible to identify a profile of the earnings management process (expressed as a dimension of discretionary accruals) within the quoted companies, according to their activity field, the type of control exerted, the reputation of the auditor, and the specificity of the expressed opinion.

\section{Research Methodology}

Through a deductive-inductive approach associated to a method that combines the precepts of positivism with those of constructivism, the present paper analyses the influence of several non-financial features of BSE-quoted companies on the quality of financial information, evaluated through their degree of earnings management.

\section{Data, population and sample}

The BSE-quoted companies make up the analysed population, and the study sample was built by excluding financial companies. An initial structuring was done according to the activity field of the companies, as shown in Figure no. 1, with the formed clusters corresponding to the economic sectors within the PIP estimation methodology.

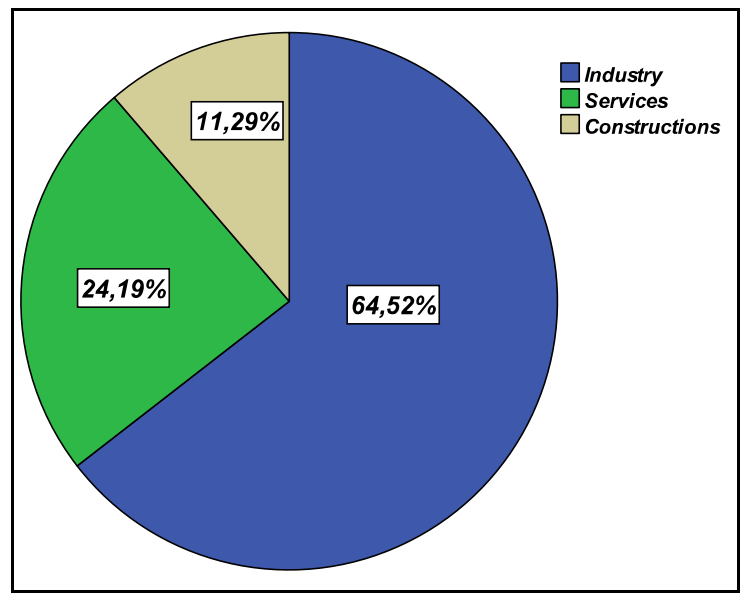

Figure 1: Distribution of the analysed companies per activity field

\section{(Source: own processing)}

The data extracted from the financial statements published by the 62 companies involved in the study, for the last 4 fiscal years (2010-2013), facilitated 248 observations on the features (variables) associated to the analysis of the earnings management process. The data were collected both from the documents published on the BSE website and from those on the companies' own websites, and they were processed using the SPSS 19 software. 


\section{Used variables and data processing methods}

The characteristics of the study units are shown through the variables synthesized in Table no. 1. We suggested variables that reflect their entire typology (numeric, category, and qualitative), according to the specificity of the used data processing methods. In this respect, significant for our research were the correlation analysis, the multiple regression analysis, the multiple regression analysis with qualitative variables, and the multiple correspondences factor analysis

\section{Table 1: Variables used in the analysis}

\begin{tabular}{|c|c|c|}
\hline Name & Symbol & Meaning \\
\hline \multicolumn{3}{|l|}{ Dependent variables } \\
\hline Total accruals & TA & $\begin{array}{l}\text { Value of the adjustments for depreciation, of the amortisation of } \\
\text { intangible assets, the variance of stocks, liabilities, and } \\
\text { commercial debt. }\end{array}$ \\
\hline Discretionary accruals & $\overline{\mathrm{DA}}$ & $\begin{array}{l}\text { Part of total accruals created intentionally by managers with the } \\
\text { purpose of managing the financial earnings }\end{array}$ \\
\hline \multicolumn{3}{|l|}{ Independent variables } \\
\hline $\begin{array}{l}\text { Variation of the sales } \\
\text { figure, reduced }\end{array}$ & $\Delta \mathrm{REV}_{\mathrm{t}}-\Delta \mathrm{REC}_{\mathrm{t}}$ & $\begin{array}{l}\text { Expresses the dynamics of the sales figure after deducting } \\
\text { commercial liabilities from its value }\end{array}$ \\
\hline $\begin{array}{l}\text { Property, plant and } \\
\text { equipment }\end{array}$ & $\overline{P P P E_{t}}$ & Size of the property, plant and equipment of the companies \\
\hline Return on assets & $\mathrm{ROA}$ & $\begin{array}{l}\text { Reflects the company's ability to remunerate the entire capital } \\
\text { used, through the result of the operational activity. It is computed } \\
\text { as the ratio between the operational result (Rop) and the total } \\
\text { assets (TAssets). }\end{array}$ \\
\hline Price-to-Book ratio & PBR & $\begin{array}{l}\text { This is the ratio between the market value and the size of the net } \\
\text { accounting asset (NAA). It reflects the investors' perception of } \\
\text { the company's performance, also showing its possibilities for } \\
\text { development. }\end{array}$ \\
\hline \multicolumn{3}{|l|}{ Category variables } \\
\hline \multirow[t]{3}{*}{ Activity field } & Ctg_Ind & Companies with an industrial activity \\
\hline & Ctg_Serv & Service providers \\
\hline & Ctg_Cons & Construction companies \\
\hline \multirow[t]{2}{*}{ Auditor category } & Ctg_Big4 & Company member of the Big4 \\
\hline & Ctg_oth & Other audit companies \\
\hline \multirow[t]{2}{*}{ Opinion } & Ctg_nrez & "No reserves" opinion \\
\hline & Ctg_wrez & "With reserves" opinion \\
\hline \multirow[t]{2}{*}{ Control } & Ctg_sing & Single control \\
\hline & Ctg_mul & Multiple control \\
\hline \multirow{2}{*}{$\begin{array}{l}\text { Earnings management } \\
\text { degree }\end{array}$} & Ctg_EM_high & High level of discretionary accruals $A \in(-\infty ;-0,245) U(0,276 ;+\infty)$ \\
\hline & Ctg_EM_low & Low level of discretionary accruals AD $\epsilon[-0,245 ; 0,276]$ \\
\hline \multicolumn{3}{|c|}{ Qualitative (dummy) variables } \\
\hline \multirow[t]{2}{*}{$\begin{array}{l}\text { Dummy_auditor } \\
\text { member a Big } 4\end{array}$} & \multirow[t]{2}{*}{ D_Big4 } & $\begin{array}{l}\text { 1- the financial statements are audited by a company member of } \\
\text { the Big } 4\end{array}$ \\
\hline & & $\begin{array}{l}0 \text { - the financial statements are audited by a company that is not } \\
\text { a member of the Big } 4\end{array}$ \\
\hline \multirow[t]{2}{*}{ Dummy_opinion } & \multirow[t]{2}{*}{ D_op } & $\begin{array}{l}\text { 1- the opinion expressed for the previous fiscal years is "no } \\
\text { reserves" }\end{array}$ \\
\hline & & $\begin{array}{l}0 \text { - the opinion expressed for the previous fiscal years is not "no } \\
\text { reserves" }\end{array}$ \\
\hline Dummy_control & D_Ctr & 1- the company has a single main shareholder \\
\hline
\end{tabular}

Mihai Carp and Iuliana Eugenia Georgescu (2016), Journal of Eastern Europe Research in Business and Economics, DOI:10.5171/2016.386814 


\begin{tabular}{|l|l|l|}
\hline Name & Symbol & Meaning \\
\hline & & 0 - the company does not have a single main shareholder \\
\hline $\begin{array}{l}\text { Dummy_main } \\
\text { shareholder Romanian }\end{array}$ & D_Shrom & 1 - the company's main shareholder is local \\
\cline { 3 - 3 } $\begin{array}{l}\text { Dummy_industrial } \\
\text { activity }\end{array}$ & D_ind & $1-$ the company's main shareholder is not local \\
\cline { 3 - 3 } & & $\begin{array}{l}0-\text { the company performs its activity in the field of industry } \\
\text { industry }\end{array}$ \\
\hline Dummy_services & D_serv & $1-$ the company's activity field is service provision \\
\cline { 3 - 3 } & & $0-$ the company's activity field is not service provision \\
\hline
\end{tabular}

(Source: own processing)

In addition to the presented variables, other control factors are such features as: the specificity of the main shareholder (private companies, investment fund), and the nationality of the capital of private companies (local, foreign). The transformation of the factor "degree of earnings management" into the presented category variables was achieved by segmenting the discretionary accruals specific to the analysed population in quartile intervals, with the proximity to the null value reflecting a low level of earnings management.

The accruals, elements that lie at the basis of the evaluation of the earnings management process, are structures derived from the application of the accrual accounting principles. Their value can be estimated by quantifying the size of the mentioned elements or by the global identification of the differences resulted from the application of the accounting treatments and techniques specific to accrual accounting, in comparison with those of cash accounting (the value of the operational cash flow minus the accounting result).

In our study, the total accruals were evaluated by quantifying the individual accounting structures, and in this sense we used the model suggested by Jones (1991). In order to insure the comparability of the data used, the value of the indicators was sized per share, with the number of securities being extracted from the statements corresponding to the prior period of our analysis.

$$
T A_{t}=\frac{\left[\left(\Delta C A_{t}-\Delta C a s h_{t}\right)-\left(\Delta C L_{t}-\Delta S T C_{t}\right)-D A E_{t}\right.}{N s_{t-1}}
$$

Where:

$\mathrm{TA}=$ total accruals for the year $\mathrm{t}$;

$\Delta C A_{t}=$ variation of the current assets in the year $t$ compared to year $\mathrm{t}-1$;

$\Delta$ Cash $_{\mathrm{t}}=$ cash variation in the year $\mathrm{t}$ compared to year $\mathrm{t}-1$;

$\Delta \mathrm{CL}_{\mathrm{t}}=$ variation of the current liabilities in the year $\mathrm{t}$ compared to year $\mathrm{t}-1$;

$\Delta \mathrm{STC}_{\mathrm{t}}=$ variation of the short-term credits in the year $\mathrm{t}$ compared to year $\mathrm{t}-1$;

$\mathrm{DAE}_{\mathrm{t}}=$ depreciation and amortization expenses during the year $\mathrm{t}$;

$\mathrm{Ns}_{\mathrm{t}-1}=$ number of shares at the end of the year $\mathrm{t}-1$.
The difficulty of the process of identifying discretionary accruals (DA), which implies deducting non-discretionary accruals from total accruals, determined the creation of a large array of econometric models that can be used to this purpose. Starting from Jones' model (1991), Kothari et al. (2005) suggest an approach for estimating non-discretionary accruals that involves the performance of the operational activity. Using the variables systematised in Table no. 1, the equation of the mentioned regression model adopted in our study can be written as follows: 


$$
\frac{T A_{t}}{N s_{t-1}}=\alpha_{1}\left(\frac{1}{N s_{t-1}}\right)+\alpha_{2}\left(\frac{\Delta R E V_{t}-\Delta R E C_{t}}{N s_{t-1}}\right)+\alpha_{2}\left(\frac{P P E_{t}}{N s_{t-1}}\right)+\alpha_{4} R O A_{t}+\varepsilon
$$

Where:

$\alpha_{1,2,3,4}=$ regression coefficients; $\varepsilon_{\mathrm{t}}=$ random variable, error (discretionary accruals).
The investors' perception of the growth perspectives of the companies, expressed by the price-to-book ratio, is a motivational factor for earnings management. For this reason, we included the mentioned indicator in the model designed to estimate nondiscretionary accruals, as an independent variable.

$$
\frac{T A_{t}}{N s_{t-1}}=\alpha_{1}\left(\frac{1}{N s_{t-1}}\right)+\alpha_{2}\left(\frac{\Delta R E V_{t}-\Delta R E C_{t}}{N s_{t-1}}\right)+\alpha_{2}\left(\frac{P P E_{t}}{N s_{t-1}}\right)+\alpha_{4} R O A_{t}+\alpha_{z} P B R_{t}+z
$$

In order to identify the intensity of the influence of non-financial characteristics on discretionary accruals, we suggest the following two econometric models: non-discretionary accruals (NDA) and on

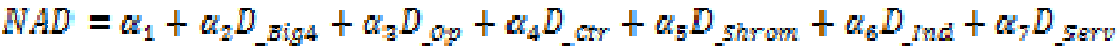

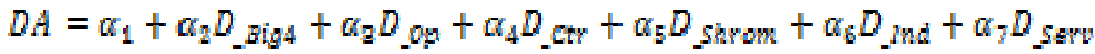

The unit values of discretionary accruals were estimated by deducting from total accruals non-discretionary accruals, obtained after the application of the presented econometric models (Kothari et al. and Kothari et al._modified) on the individual data specific to the economic entities that make up the analysed sample.

\section{Interpretation of the results obtained}

The multitude of features (legal, financial, occupational, etc.) that individualise economic entities make up, together with the general economic environment, factors that influence the quality of the financial information reported by these companies. The neutrality of the published information, quantified through the extent of earnings management, is a direction of study in this field.

Testing hypothesis $\mathrm{H} 1$, which anticipates the disjunctive effect of some non-financial factors on the effort of appreciating the quality of the financial information reported by the companies quoted on the main section of the BSE, allowed obtaining the results synthesised in Table no. 2. Quantified by the dimension of discretionary accruals (DA), the level of earnings management is statistically reflected in the dimension of the random error factor $(\epsilon)$, present in the econometric models for estimating the contribution of non-discretionary accruals (NDA) to explaining the variance of total accruals (TA). Concretely, $\epsilon$ is computed by deducting the determination ratio $\mathrm{R}^{2}$ from the maximum value possible of the influences of the independent variables upon the dependent variable $\left(\epsilon=1-\mathrm{R}^{2}\right)$.

The analysis performed on the clusters formed according to the selected control variables facilitated the sequential evaluation of the level of earnings management, allowing at the same time to identify the characteristics that determine variances of this indicator, with positive valences concerning the solutions for restricting the debated phenomenon. 
Using a modified econometric model, complementary to the model of Kothari et al. (2005), aimed to adapt the evaluation approach of non-discretionary accruals to the specificity of the Romanian investment environment, with the perspectives of increasing the market value in relation to the dimension of the accounting value (the expression of PBR) being a robust indicator, present in the analyses performed on the funding process through the domestic capital market. We can thus notice that the inclusion of PBR generates a better explanatory capacity of non-discretionary accruals, therefore a better accuracy of the models $\left(\mathrm{R}^{2}\right.$ total sample_Km $=0,287>\mathrm{R}^{2}$ total sample_K$\left.=0,273\right)$.

The evaluation of the extent of earnings management according to the companies' activity field reveals a low quality of the information reported by the entities in the field of constructions $\left(\epsilon_{\text {constructions_K }}=0,838\right)$, significantly lower than that identified for the subjects in industry $\left(\epsilon_{\text {industry_K}}=0,582\right)$, respectively services $\left(\epsilon_{\text {services_K }}=0,608\right)$. This situation reflects the vulnerability of construction companies, also determined by the significant volatility of this economic segment, profoundly affected by the last economic crisis. The need to preserve the funding sources (capital market or creditors), as well as the specificity of this activity, which allows little control over the consumed resources, can represent motivational factors for performing actions that lead to the alteration of the financial information presented in annual reports.
The development and diversification of the services sector, as well as the restructuring of the productive segment of economy, with the companies' adapting to the requirements of the international market or through the creation of new entities, lead to an intensified competition in this field, which generated an increased concern with external image, with additionally a positive effect on the quality of the financial information provided to the users.

In this context of the interest in informing all the user categories and especially investors, a determinant role is played by the process of certification of the financial statements, where the reputation of the audit companies and the expressed opinion are influence factors concerning the neutrality of the published information. Thus, for the analysed sample, we noticed a favourable contribution of the financial statements being audited by companies member of the Big4, in comparison with the situation of the certification by other auditors of the compliance of the annual statements with the applicable legislation $\left(\epsilon_{\mathrm{Big} 4_{-} \mathrm{K}}=0.818<\right.$ $\epsilon_{\text {Other_comp_K }}=0.859 ; \quad \epsilon_{\text {Big4_Km }}=0.799<$ $\epsilon_{\text {Othere_comp_Km }}=0.835$ ). The superior specialty of the Big4 companies in what concerns detecting management actions is an element that restricts the intensions of altering the financial information.

Table 2: Results of the sequential analysis on the level of earnings management

\begin{tabular}{|c|c|c|c|c|c|c|c|c|c|}
\hline $\begin{array}{c}\text { Resulting } \\
\text { TA }\end{array}$ & $\begin{array}{l}\text { Intercept } \\
\alpha_{1}\end{array}$ & $\frac{\Delta R E V_{t}-\Delta R E C_{t}}{N s_{t-1}}$ & $\frac{P P E_{t}}{N s_{t-1}}$ & $\overline{R O A_{\bar{t}}}$ & $\overline{P B R_{t}}$ & $\varepsilon$ & $R^{2}$ & $N$ & $\overline{S I G}$ \\
\hline Total sample $_{K}$ & -0.169 & 0.165 & -0.473 & 0.128 & & 0.727 & 0.273 & 248 & 0.000 \\
\hline Total sample $\mathrm{Km}$ & -0.478 & 0.165 & -0.463 & 0.124 & 0.040 & 0.713 & 0.287 & 248 & 0.000 \\
\hline \multicolumn{10}{|l|}{ Activity field } \\
\hline Industry_K & -0.349 & 0.025 & -0.648 & 0.025 & & 0.582 & 0.418 & 159 & 0.000 \\
\hline Industry_Km & -0.682 & 0.025 & -0.635 & 0.026 & 0.044 & 0.584 & 0.416 & 159 & 0.000 \\
\hline Services $_{K}$ & -1.097 & 0.297 & 0.434 & 0.207 & - & 0.608 & 0.392 & 60 & 0.000 \\
\hline Services $_{\mathrm{Km}}$ & -1.892 & 0.315 & 0.336 & 0.257 & 0.066 & 0.598 & 0.402 & 60 & 0.000 \\
\hline$\overline{\text { Construction }}$ & 0.018 & -0.085 & -0.349 & 0.018 & & 0.838 & 0.162 & 27 & 0.030 \\
\hline
\end{tabular}

Mihai Carp and Iuliana Eugenia Georgescu (2016), Journal of Eastern Europe Research in Business and Economics, DOI:10.5171/2016. 386814 


\begin{tabular}{|c|c|c|c|c|c|c|c|c|c|}
\hline $\begin{array}{c}\text { Resulting } \\
\text { TA }\end{array}$ & $\begin{array}{l}\text { Intercept } \\
\alpha_{1}\end{array}$ & $\frac{\Delta R E V_{t}-B R E C_{t}}{N s_{t-1}}$ & $\frac{P P E_{t}}{N s_{t-1}}$ & $\mathrm{ROA}$ & $P B R_{t}$ & $\bar{\varepsilon}$ & $R^{2}$ & $N$ & $\overline{S I G}$ \\
\hline Constructions $_{\mathrm{Km}}$ & 0.119 & -0.075 & -0.241 & 0.216 & -0.360 & 0.761 & 0.239 & 27 & 0.162 \\
\hline \multicolumn{10}{|l|}{ Auditor category } \\
\hline Member Big $4_{K}$ & -0.016 & -0.187 & 0.021 & -0.360 & - & 0.818 & 0.182 & 79 & 0.013 \\
\hline Member Big $4_{\mathrm{Km}}$ & 0.056 & -0.186 & 0.016 & -0.019 & -0.109 & 0.799 & 0.201 & 79 & 0.027 \\
\hline Other companies $\mathrm{K}$ & 0.027 & -0.006 & -0.112 & 0.189 & - & 0.859 & 0.141 & 169 & 0.000 \\
\hline $\begin{array}{l}\text { Other } \\
\text { companies_ } \mathrm{Km} \\
\end{array}$ & 0.059 & -0.026 & -0.119 & 0.285 & 0.040 & 0.835 & 0.165 & 169 & 0.000 \\
\hline \multicolumn{10}{|l|}{ Expressed opinion } \\
\hline No reserve $_{\mathrm{K}}$ & 0.002 & 0.031 & -0.083 & 0.310 & - & 0.888 & 0.112 & 166 & 0.001 \\
\hline No reserve $_{\mathrm{Km}}$ & 0.036 & 0.013 & -0.090 & 0.466 & -0.051 & 0.874 & 0.126 & 166 & 0.002 \\
\hline With reserve $_{\mathrm{K}}$ & 0.007 & -0.227 & 0.013 & -0.047 & - & 0.690 & 0.310 & 82 & 0.000 \\
\hline With reserve $_{\mathrm{Km}}$ & 0.116 & -0.259 & 0.024 & 0.985 & -0.207 & 0.609 & 0.391 & 82 & 0.000 \\
\hline \multicolumn{10}{|l|}{ Control } \\
\hline Single $_{K}$ & 0.007 & 0.039 & -0.060 & 0.322 & - & 0.918 & 0.082 & 144 & 0.017 \\
\hline Single $_{\mathrm{Km}}$ & 0.040 & 0.020 & -0.065 & 0.552 & -0.052 & 0.910 & 0.090 & 144 & 0.046 \\
\hline Multiple $_{\mathrm{K}}$ & 0.001 & -0.294 & 0.007 & -0.189 & - & 0.724 & 0.276 & 104 & 0.000 \\
\hline Multiplu $_{\mathrm{Km}}$ & 0.037 & -0.294 & -0.010 & -0.111 & -0.056 & 0.717 & 0.283 & 104 & 0.000 \\
\hline \multicolumn{10}{|l|}{ Main shareholder } \\
\hline $\begin{array}{l}\text { Private } \\
\text { companies }_{K}\end{array}$ & 0.016 & 0.143 & -0.088 & 0.185 & - & 0.818 & 0.182 & 96 & 0.001 \\
\hline $\begin{array}{l}\text { Private } \\
\text { companies }_{\mathrm{Km}}\end{array}$ & 0.048 & 0.113 & -0.091 & 0.212 & 0.031 & 0.831 & 0.169 & 96 & 0.013 \\
\hline Investment fund ${ }_{K}$ & -0.043 & 0.060 & 0.164 & 0.474 & - & 0.218 & 0.782 & 32 & 0.000 \\
\hline $\begin{array}{l}\text { Investment } \\
\text { fund }{ }_{\mathrm{Km}}\end{array}$ & -0.086 & 0.067 & 0.174 & 0.265 & 0.108 & 0.187 & 0.813 & 32 & 0.000 \\
\hline \multicolumn{10}{|c|}{ Capital nationality (private companies) } \\
\hline Local $_{K}$ & 0.059 & 0.141 & -0.087 & -0.127 & - & 0.763 & 0.237 & 36 & 0.052 \\
\hline Local $_{\mathrm{Km}}$ & 0.078 & 0.133 & -0.091 & 0.089 & -0.027 & 0.757 & 0.243 & 36 & 0.125 \\
\hline Foreign $_{\mathrm{K}}$ & 0.005 & 0.131 & -0.096 & 0.162 & - & 0.854 & 0.146 & 60 & 0.040 \\
\hline Foreign $_{\mathrm{Km}}$ & 0.026 & 0.078 & -0.104 & 0.192 & -0.016 & 0.880 & 0.120 & 60 & 0.290 \\
\hline
\end{tabular}

\section{(Source: own processing in SPSS)}

Feature ${ }_{\mathrm{K}}$-results obtained using the model of Kothari et al. (2005)

Feature $\mathrm{Km}^{-}$results obtained using the model of Kothari et al. (2005)_modified

Also, the specificity of the opinion expressed for the fiscal year previous to the analysed year may be a factor that determines the information quality. Thus, in case a "with reserve" opinion is issued for the financial statements for the previous period, we can notice an improvement of the quality of the published information, reflected through a low level of DA, in comparison with the situation when a "no reserve" opinion is expressed $\quad\left(\epsilon_{\text {With_reserve_K }}=0.690<\right.$ $\epsilon_{\text {No_reserve_K }}=0.888 ; \quad \epsilon_{\text {With_reserve_Km }}=0.609<$ $\epsilon_{\text {No_reserve_Km }}=0.799$ ), stressing at the same time the coercive role of external financial audit.

The shareholders' characteristics are another dimension that affects the quality of the reported financial information. Features such as the type of control exerted (single or multiple), the specificity of the main shareholder (investment fund or private company), and the nationality of the invested capital (foreign or local) are other determinant factors of the level of earnings management. 
According to the data grasped in Table no. 2, in the case of companies controlled by a single shareholder, we can notice a high level of earnings management ( $\epsilon_{\text {Single_control_K }}=0.918$; $\left.\epsilon_{\text {Single_control_Km }}=0.910\right) . \quad$ A combined ownership of the majority of stocks generates a drop of this indicator $\left(\epsilon_{\text {Multiple_control_K }}=0.727\right.$;

$\epsilon_{\text {Multiple_control_Km }}=0.717$ ), explained by the elimination of any possible pressure concerning the process of drawing the financial statements, derived from the power position of the single shareholder. From the comparative analysis performed on the specificity of the shareholders, we can see a net quality superiority of the financial information published by the companies whose main shareholder is represented by investment funds, in comparison with the situation in which the control is exerted by private companies $\left(\epsilon_{\text {Investment_fund_K } \mathrm{K}}=0.218<\right.$ $\epsilon_{\text {Private_company_K }}=0.818 ; \epsilon_{\text {Investment_fund_Km }}=0.187<$ $\epsilon_{\text {Private_company_Km }}=0.831$ ). The explanation can be found in the nature of the organisational objectives of capital owners. If the investment funds strictly aim to render their portfolio more profitable, in order to generate benefits for a large category of contributors (which are, at the same time, a pressure factor for decision makers), private companies aim at diverse objectives that can be linked to the results of a group of entities or even to the use of quoted branches that perform niche activities, with a limited time horizon.

The nationality of the capital provided by private companies, which already own the majority of contributions, generate a slightly disconcerting result distribution, as the degree of earnings management recorded for the entities with foreign shareholders exceeds the level identified for the sub-group of subjects controlled by local private companies $\quad\left(\epsilon_{\text {Foreign_capital_K }}=0.854>\right.$ $\epsilon_{\text {Local_capital_K }}=0.763 ; \quad \epsilon_{\text {Foreign_capital_Km }}=0.880>$ $\epsilon_{\text {Local_capital_Km }}=0.757$ ). The foreign shareholders bring to the companies created in countries with emerging economies efficient activity management practices, including the financial-accounting field. The results obtained require a more detailed analysis, with the purpose of identifying the origin countries of the capital, since there is a possibility for the contributions of the foreign companies in Romanian economic entities to be means for creating fiscal benefits, through the relocation of the obtained profit, and the earning management practices fully serve these objectives.

The multiple correspondences factor analysis facilitated the identification of a profile of the degree of financial earnings management, which reflects a series of causal relationships between the various perspectives of the analysed phenomenon, grasped through the control variables.

Based on Euclidian distances that characterise the point cloud associated to the category variables involved into the analysis, the resulting diagram is presented in Figure $n r .2$. Thus, with the purpose of performing a multi-criteria analysis, the category variables created were integrated in the study, facilitating the estimation of simultaneous influences on the extent of earnings management. This approach reveals that a low level of EM is recorded for the entities that perform in the field of services, whose financial statements are generally certified by non-Big4 companies, and which mainly express a "no reserve" opinion on their quality. Also, the control of the entities in this category is exerted in a group, an element that corresponds to the unidirectional analysis previously performed.

A higher level of EM mainly characterises industrial companies controlled by a single shareholder. Their annual reports were audited by companies that are members of the Big4, which generally issued a "reserve" on the contents of the financial statements corresponding to the previous fiscal year, in compliance with the applicable accounting norms. 


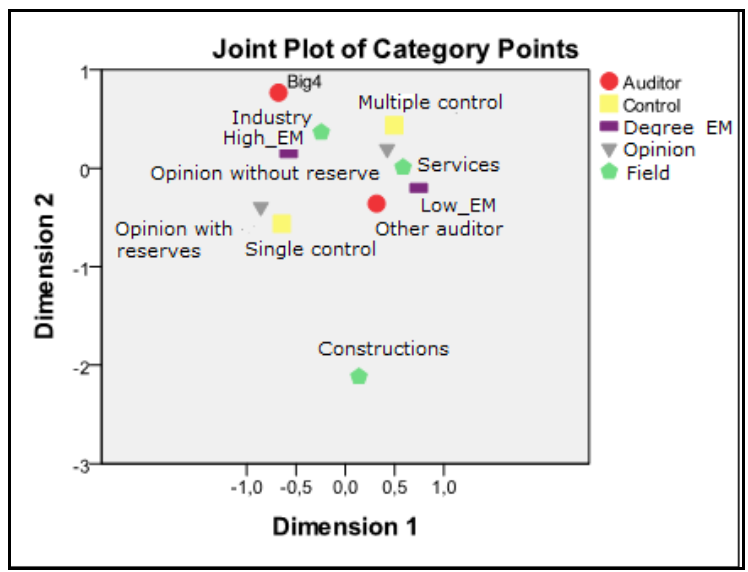

Figure 2: Association relationships identified in the analysis of the management of the earnings reported by BSE-quoted companies

\section{(Source: own processing in SPSS)}

In order to identify the sense of action and to quantify the influences exerted by qualitative factors on the accruals recorded by the quoted Romanian companies, we used the multiple regression analysis with dummy variables, and the results obtained are synthesised in Table no. 3. This approach was performed both for the total accruals (TA) and for the structural components, respectively discretionary accruals (DA) and non-discretionary accruals (NDA).

Table 3: Influence of the qualitative variables on the level of discretionary accruals

\begin{tabular}{|c|c|c|c|c|c|}
\hline \multirow{4}{*}{$\begin{array}{c}\text { Qualitative } \\
\text { independent } \\
\text { variables }\end{array}$} & \multicolumn{5}{|c|}{ Dependent variables (accruals) } \\
\hline & \multirow{2}{*}{$T A$} & \multicolumn{2}{|c|}{ Model Kothari et al. } & \multicolumn{2}{|c|}{ Model Kothari et al._mofied } \\
\hline & & $N D A$ & $D A$ & $N D A$ & $D A$ \\
\hline & \multicolumn{5}{|c|}{ Regression coefficients } \\
\hline Intercept & -0.042 & -0.474 & 0.376 & -0.617 & 0.583 \\
\hline D_Big4 & 0.028 & 0.013 & -0.048 & -0.016 & -0.011 \\
\hline D_op & -0.028 & 0.337 & -0.315 & 0.001 & 0.011 \\
\hline D_ctr & 0.093 & -0.057 & 0.228 & -0.088 & 0.085 \\
\hline D_Orom & -0.045 & 0.113 & -0.177 & 0.026 & -0.018 \\
\hline D_Ind & -0.006 & 0.164 & -0.206 & 0.036 & -0.042 \\
\hline D_Serv & -0.062 & 0.164 & -0.320 & 0.148 & -0.127 \\
\hline$N^{\circ}$ obs. $-N$ & 248 & 248 & 248 & 248 & 248 \\
\hline$R^{2}$ & 0.021 & 0.127 & 0.099 & 0.160 & 0.121 \\
\hline SIG (model) & 0.609 & 0.000 & 0.001 & 0.000 & 0.007 \\
\hline
\end{tabular}

(Source: own processing in SPSS)

The unitary values of DA and NDA were obtained by applying the models of Kothari et al. and Kothari et al._modified on the individual data of the subjects that form the work sample. The significant dispersion of the characteristics of the analysed entities is also confirmed by the statistically insignificant results revealed after testing the deterministic relationship within total accruals (SIG=0.609). Nevertheless, the 
correlations established between the dummy variables taken into consideration in the study and the level of discretionary accruals, respectively non-discretionary accruals, confirm the sense of the connections identified through the sequential analysis previously performed. The values of the regression coefficients attached to each factor provide the dimension of their influence on the resulting variable. Thus, the level of discretionary accruals, as an exponent of the level of earnings management, is diminished by the presence of the following characteristics: auditing of the financial statements by a Big4 company, expressing a "no reserve" opinion, the presence of a main Romanian shareholder, and in the case of entities that perform in the field of industry, respectively services. Whenever these features are present, NDA rises, which represents a favourable situation due to the complementarity relationship between the two components of total accruals.

Nevertheless, the presence of interpretative inconsistencies for one variable (expressed opinion), in the model of Kothari et al., reflects the need to design new models for estimating the NDA, adapted to the specificity of national economies.

\section{Conclusions}

The efficiency of the investment process performed on financial markets is conditioned by the existence of factors that limit the uncertainties associated with the approach of placing the available capital. From this point of view, the quality of the financial information reported by the quoted companies is a determinant factor of the stability of this capital transfer space. The faithful representation of the economic reality, through a neutral approach on drawing the financial statements, contributes to a correct support of the investment decisions. Nevertheless, the existence of motivational factors, both at an individual level (of the managers) and at the level of organisational objectives concerning the management of published earnings, justifies the need for research aimed to estimate the degree of credibility of the financial information.

The present paper analyses the influence of the non-financial features of quoted companies on the intensity of the earnings management process.

Validating hypothesis $\mathrm{H} 1$ leads to estimating the level of earnings management in relation to a series of representative characteristics of quoted Romanian companies, related to the activity field, the shareholders' structure, and the process of certification of the financial statements. Using the mentioned control variables as a disjunctive factor, we identified the higher quality level of the financial information published by companies whose annual reports were audited by entities member of the Big4, respectively for which a "with reserve" opinion was expressed in what concerned the compliance of the financial statements with the applicable norms (for the previous fiscal year). Also, companies that perform in the field of services, as well as those activating in industry have a lower DA level than that specific to entities in constructions. The inclusion into the analysis of the variables that reflect the owners ' properties revealed the low level of earnings management in the case of companies owned by minority shareholders in a group, and in the case of companies with a majority shareholder, the qualitative superiority of the information reported by entities controlled by investment funds.

A profile on the process of management of the financial information performed within the quoted entities (expressed as a dimension of discretionary accruals) was obtained after hypothesis $\mathrm{H} 2$ was tested. The suggested multi-criteria causal relationships reflected an association of the common control and of expressing an opinion "with reserve" by non-Big4 auditors with a low level of EM, recorded for companies in the field of services. A high level of EM 
corresponds to industrial companies, when an opinion "without reserve" is expressed by auditors who are members of the Big4 and when they are controlled by a single shareholder. The monitored association relationships proved inconsistent for the entities in the field of constructions.

By estimating the influences of the qualitative variables on the level of the two accrual components (NDA and DA), we confirmed to a great extent the previously identified deterministic relationships, although deviations could also be noticed from the sense of the connections obtained in the sequential analysis performed.

The lack of correlation between the results shown by various analysis methods represents the limitations of the present study; eliminating them by adapting the econometric models to the reality of the local economy, together with increasing the number of observations performed, could be future research directions.

\section{Acknowledgment}

This work was supported by the strategic grant POSDRU/159/1.5/S/133652, cofinanced by the European Social Fund within the Sectorial Operational Program Human Resources Development 2007 - 2013.

\section{References}

1. Abernathy, J. L., Beyer, B. and Rapley, E. T. (2014), 'Earnings Management Constraints and Classification Shifting', Journal of Business Finance \& Accounting, 41 (5-6), 600626

2. Berheci, M. (2010), Valorificarea raportărilor financiare: sinteze contabile: teorie, analize, studii de caz, CECCAR, Iași

3. Copeland, R. M. (1968), 'Income smoothing', Journal of Accounting Research, 6, 101-116
4. Datta, S., Iskandar-Datta, M. and Singh, V. (2013), 'Product market power, industry structure, and corporate earnings management', Journal of Banking \& Finance, 37 (8), 3273-3285

5. El Mehdi, K.I. and Seboui, S. (2011), 'Corporate diversification and earnings management', Review of Accounting and Finance, 10 (2), 176 - 196

6. Francis, J., Schipper, K. and Vincent, L. (2003), 'The Relative and Incremental Explanatory Power of Earnings and Alternative (to Earnings) Performance Measures for Returns', Contemporary Accounting Research, 20 (1), 121-164

7. Ge, W. and Kim, J. B. (2014), 'Real earnings management and the cost of new corporate bonds', Journal of Business Research, 67 (4), 641-647

8. Ghosh, S. (2011), 'Firm ownership type, earnings management and auditor relationships: evidence from India', Managerial Auditing Journal, 26 (4), 350 369

9. Haw, I. M., Ho, S. S. and Li, A. Y. (2011), 'Corporate Governance and Earnings Management by Classification Shifting', Contemporary Accounting Research, 28 (2), 517-553

10.Healy, P. M. and Wahlen, J. M. (1999), 'A review of the earnings management literature and its implications for standard setting', Accounting Horizons, 13 (4), 365-383

11.Iatridis, G.E. (2011), 'Accounting disclosures, accounting quality and conditional and unconditional conservatism', International Review of Financial Analysis, 20, 88-102

12.Iqbal, A. and Strong, N. (2010), 'The effect of corporate governance on earnings management around UK rights issues', International Journal of Managerial Finance, 6 (3), 168-189

Mihai Carp and Iuliana Eugenia Georgescu (2016), Journal of Eastern Europe Research in Business and Economics, DOI:10.5171/2016.386814 
13.Jones, J. J. (1991), 'Earnings Management During Import Relief Investigations', Journal of Accounting Research, 29 (2), 193-228

14.Kothari, S. P., Leone, A. J. and Wasley, C. E. (2005), 'Performance matched discretionary accrual measures', Journal of Accounting \& Economics, 39, 163-197

15.Lee, S. P. and Chen, H. J. (2011), 'Corporate governance and firm value as determinants of CEO compensation in Taiwan 2SLS for panel data model', Management Research Review, 34 (3), 252-265

16.Lev, B. (1989), 'On the usefulness of earnings and earnings research: Lessons and directions from two decades of empirical research', Journal of Accounting Research, 27, 153-192

17.McKee, T. (2005), Earnings management: an executive perspective, Thomson Higher Education, Mason

18.McVay, S. E. (2006), 'Earnings Management Using Classification Shifting: An Examination of Core Earnings and Special Items', The Accounting Review, 81, 501-531

19.Omar, N., Rahman, R.A., Danbatta, B.L. and Sulaiman, S. (2014), 'Management disclosure and earnings management practices in reducing the implication risk', Procedia Social and Behavioral Sciences, 145, 88 - 96

20.Parfet, W. U. (2000), 'Accounting subjectivity and earnings management: A preparer perspective', Accounting Horizons, 14 (4), 481-488

21.Rankin, M., Stanton, P. A., McGowan, S. C., Ferlauto, K. and Tilling, M. (2012), Contemporary issues in accounting, Wiley, Milton

22.Ronen, J. and Yaari, V. (2008), Earnings management: emerging insights in theory, practice, and research, Springer, New York

23.Rusmin, R. (2010), 'Auditor quality and earnings management: Singaporean evidence', Managerial Auditing Journal, 25 (7), $618-638$

24.Schipper, K. (1989), 'Commentary on earnings management', Accounting Horizons, 3 (4), 91-102

25.Sun, J., Lan, G. and Liu, G. (2014), 'Independent audit committee characteristics and real earnings management', Managerial Auditing Journal, 29 (2), 153-172

26.Tsipouridou, M. and Spathis, C. (2012), 'Earnings management and the role of auditors in an unusual IFRS context: The case of Greece', Journal of International Accounting, Auditing and Taxation, 21 (1), pp. 62-78

27.Zang, A. Y. (2012), 'Evidence on the TradeOff Between Real Activities Manipulation and Accrual-Based Earnings Management', The Accounting Review, 87, 675-703 